\title{
THE EFFECTS OF INTERNET SHOPPERS' TRUST ON THEIR PURCHASING INTENTION IN CHINA
}

\author{
Rong Li \\ Amazingsoft, Inc. \\ JaeJon Kim \\ BK21 Biz Convergence Team, Chonnam National University, Korea \\ JaeSung Park \\ Chonnam National University, Korea
}

\begin{abstract}
Owing to the rapid development of the Internet and information technology in China, the growth of consumers' purchasing activities in Internet shopping malls has been truly phenomenal in recent years. Taobao.com, Ebay.com.cn, and Paipai.com have 67,360,000 customer to customer (C2C) users and $99 \%$ of the market share in China's C2C market (www.163.com). Dangdang.com and Joyo.com have occupied $87 \%$ of the business to customer (B2C) market with $58,360,000$ users (www.sohu.com). Because of these significant numbers of users, it is important to understand what affects Chinese consumers' decisions to purchase in Internet shopping malls. Based on past studies, trust is considered a key factor affecting a Chinese consumer's purchasing intention. The purpose of this study is to investigate the effects of Chinese shoppers' trust on their purchasing intention in Internet shopping malls. In order to accomplish the purpose of this study, we developed a research model. This model suggests that there exists a significant relationship between trust and purchasing intention. According to this model, on purchasing intention, trust also mediates effects of other independent variables such as e-commerce knowledge, perceived reputation, perceived risk, and perceived ease of use. The results of this study show that the relationships between these variables are all significant except that between
\end{abstract}

Recebido em/Manuscript first received: 05/10/2007 Aprovado em/Manuscript accepted: 30/11/2007

Endereço para correspondência/ Address for correspondence

Rong $\mathrm{Li}$ is graduated from Fudan University (China) in 2005 and got his master's degree in Electronic Commerce from Chonnam National University (Korea) in 2007. He is currently a staff of Amazingsoft, Inc. providing Web Analytics service for global customers. His research concentrates on e-Commerce in East Asia, Online Marketing and Search Engine Optimization. E-mail: lirong1229@hotmail.com

JaeJon Kim is Professor of Information Systems at the School of Business Administration, Chonnam National University, Korea. He received his Ph.D. degree in Computer Information Systems from Arizona State University in the U.S.A. His current research interests are strategic use of information technology including E-business and IT-enabled innovation. E-mail: jaejon@chonnam.ac.kr

JaeSung Park received his M.A. degree in Management Information System from Chonnam National University in Korea. He is currently a Senior Research Associate at the Business Incubator, Chonnam National University, Korea. His research interests include Management Information Systems, E-Business Start-up, and Web Analytics. E-mail: pamto@jnu.ac.kr

Chonnam National University. Gwangju Campus 300 Yongbong dong, Buk-gu, Gwangju 500-757, Korea

ISSN online: $1807-1775$

Publicado por/Published by: TECSI FEA USP - 2007 
trust and perceived reputation. This research confirms the significant effects of Chinese shoppers' trust on purchasing intention. Implications of these findings are discussed for researchers and practitioners.

Keywords: Internet shopping mall, purchasing intention, trust, e-commerce knowledge, reputation, risk, PEOU

\section{INTRODUCTION}

Since 1997, China's information industry has been developing very rapidly. According to the 19th Statistical Survey Report on Internet Development in China released in January 2007 by the China Internet Network Information Center (CNNIC, 2007), the number of Internet users has reached 137 million. Of these users, 79.1\% said that they would surely or possibly go Internet shopping in the first half of the year. $23.6 \%$ of the users replied that they were frequently using an Internet shopping service when they went on the Internet. In 2006, there were over 30 million Internet users who had an Internet shopping experience.

Despite the fact that Internet shopping malls are now winning more and more customers by providing these customers with a discounted price for products, favorable price alone may not be sufficient. Trust is still regarded as an order qualifier for consumers' purchase decisions (Doney \& Cannon, 1997). Consumers are unlikely to patronize Internet stores that fail to create a sense of trust (Jarvenpaa \& Tractinsky, 1999). Trust can only exist if the consumer believes that the seller has the ability to provide and deliver goods of the quality expected by the consumer. At this point in time, there is another important question: How can consumers gain trust in an Internet shopping mall? In traditional contexts, a consumer's trust has been found to be affected by the seller's investment in physical buildings, facilities, and personnel (Doney \& Cannon, 1997). We note, however, that since there is no physical contact between consumers and sellers in an Internet shopping mall, it is reasonable to suggest that a consumer's trust is affected by the consumer's characteristics, instead of some actions of the seller's .

The purpose of this study has been to identify factors which may affect the purchasing intention in $\mathrm{B} 2 \mathrm{C}$ market and examine the relationships among the identified factors. For this purpose, we conducted an empirical study on Chinese users using Internet shopping malls.

\section{THEORETICAL BACKGROUND}

\subsection{Trust}

Trust has been conceptualized by many prior researchers. In this paper, we only discuss the concept of trust in an Internet shopping mall (or e-commerce context) because the concept of "trust" is so broad. We, now, briefly discuss several prior 
research studies dealing with the conceptualization of trust in an e-commerce context.

Jarvenpaa \& Tractinsky (1999) define trust in the Internet shopping mall context as a consumer's willingness to rely on the seller and take action in circumstances where such action makes the consumer vulnerable to the seller. According to Mayer et al. (1995) trust is a willingness of a party to be vulnerable to the actions of another party based on the expectation that the other party will perform a particular action important to the vulnerable party, irrespective of the vulnerable party's agility to monitor or control that other party. Kim et al. (2004) define trust as the belief that the other party will behave in a dependable manner in an exchange relationship. Trust, in this study, is broken down into two constructs according to different trust subjects: (1) potential consumer trust is referred to as the initial trust that a potential customer has in an unfamiliar trustee, and (2) repeat consumer trust is referred to as the trust that a repeat customer has in a familiar trustee after having some transaction experience with the trustee. McKnight et al. (1998) also divide trust into two constructs: (1) trusting intention, meaning that one person is willing to depend on the other person in a given situation, and (2) trusting beliefs, meaning that one person believes the other person is benevolent, competent, honest, or predictable in a situation.

David Gefen and his colleagues' (2003) construct a table which provides a summary of the prior conceptualizations of trust along with the trust object and measures used to operationalize the construct. As a result, the table shows that researchers' view of trust can be separated into 4 divisions:

(1) A set of specific beliefs dealing primarily with the integrity, benevolence, and ability of another party.

(2) A general belief that another party can be trusted.

(3) Affect reflected in "feelings" of confidence and security in the caring response of the other party

(4) A combination of these elements.

In e-commerce contexts, when neither the buyer nor seller can be face-to-face with the other party directly, uncertainty exists all the time because of both parties' unpredictable action and opportunistic behavior (Jang et al., 2005). Hence, the key to removing this kind of uncertainty and making successful economic transactions is avoiding opportunistic behavior (Hosmer, 1995). In this case, any general belief or feeling without evidence cannot be regarded as equivalent to "trust". Real trust, therefore, can only exist if the consumer believes that the seller has the ability to provide and deliver goods of expected or better quality as a consequence of the consumer's Internet shopping behavior. With such definitions and distinctions in mind, trust or consumer trust is operationally defined for our study as "a set of specific beliefs dealing primarily with the integrity, benevolence, and ability of another party."

The trust object in Internet shopping malls is totally different from that in an offline store. That is to say, due to no seller-related management apparent during buying or selling in the Internet shopping mall, the subject of consumer trust becomes the Internet shopping mall itself (Jong \& Lee, 2000). Thus trust plays an important role during the transaction in this uncertain and risky circumstance. 


\subsection{E-commerce Knowledge}

E-commerce knowledge means a customer's knowledge of e-commerce related technology and basic knowledge necessary for actually using e-commerce. This kind of knowledge includes the know-how and skill of accomplishing an e-transaction activity and using the various kinds of technologies and methods required to perform an etransaction (Baek et al., 2006). E-commerce knowledge can be broken into two divisions: "skill" and "control or familiarity". While "skill" refers to the Web consumer's capacity for action during the online navigation process, "control or familiarity" comes from both the Web user's perception of their ability to successfully navigate the Web environment and their perception of how the Web responds to their inputs (Novak et al., 2000). "Control" is considered as necessary as an external condition for a customer's Internet shopping. "Control", in this context, is similar to a kind of external equipment such as a computer used when the customer is connected to the Internet. While engaged in an online pursuit, the skills and familiarity of consumers must be above a critical threshold (Novak et al., 2000).

In this paper, e-commerce knowledge is defined as knowledge about product searching through the Internet shopping mall, the purchasing method, the payment process and the mall's personal information protection policy, etc.

\subsection{Perceived Reputation}

A customer may have perception of an Internet shopping mall's reputation (Jong $\&$ Lee, 2000). The perceived reputation of an Internet shopping mall provides assurances about the seller's ability, integrity, and goodwill (Jarvenpaa \& Tractinsky, 1999). It is the extent to which buyers believe that the selling organization is honest and concerned about its customers (Doney \& Cannon, 1997). It also can be referred to as a customer's recognition of the seller based on indirectly collected information from friends, relatives, colleagues, etc. (Lee \& Lee, 2003). Doney \& Cannon (1997) suggest that the costs to an Internet shopping mall acting in an untrustworthy manner are quite high for an e-vendor with a good reputation. In the China $\mathrm{C} 2 \mathrm{C}$ market, high-reputation Internet shopping malls have occupied almost all of the entire market. Taobao.com has already taken $67.3 \%$ of the online auction market share in China (www.chinatechnews.com). Hence, it is considered necessary to study more deeply the relationship between perceived reputation and costumer trust.

\subsection{Perceived Risk}

Perceived risk was first introduced in the field of consumer activity (Yang \& Baeg, 2003). Nowadays, even though there are a number of transactions that include safety mechanisms being developed, consumers still feel uneasy (risky) in participating in transactions in virtual space (Park, 2005). The past studies show two different views on the perceived risk: (1) the uncertainty on the result after online selection of a product or service, and (2) the expected loss that could result by the online selection. Perceived risk can be defined as consumer's perceptions of the uncertainty and adverse 
consequences of engaging in an activity (Dowling \& Staelin, 1994). It is a kind of subjective risk completely different from the objective risk that can be expressed as a probability. In other words, only if a consumer perceives the problem by himself/herself (subjectively) will the problem be evident to the consumer, even though the problem has been a real problem in reality for a long time (Yang \& Baeg, 2003).

Several distinct types of perceived risk have been defined in the previous research. As Jarvenpaa \& Tractingsky (1999) point out, a probable difference in physical goods with respect to quality as perceived by a consumer is a main type of perceived risk.

There are other types of perceived risk such as a consumer's perceived wariness about possible leakage of credit card related information, a consumer's perceived lack of feeling secure about protection of personal information (Ratnasingham, 1998; Jeong et al., 2004), a consumer's perceived wariness about the possibility of no-refund or noreturn after ordering (Jeong et al., 2004).

In addition, some other studies like one by Kim \& Park (1999) classify perceived risk into a functional trust risk, a payment method risk, a contract related risk, and a delivery related. In their paper, Kim \& Park define perceived risk as a consumer's perceptions of the uncertainty and adverse consequences of engaging in an activity. The comprehensive definition by Dowling \& Staelin (1994) includes the notions of a consumer's perception of the probable difference of the quality of the physical goods, the possibility of no-refund and no-return on the order, danger from the payment method, lack of personal information protection, and the probable long delivery time.

\subsection{Perceived Ease of Use (PEOU)}

In essence, a Web site is actually a kind of information technology. The technology acceptance model (TAM) has been used in the study of IT acceptance for recent decades. Perceived ease of use (PEOU), a major construct of TAM, is an indicator of the cognitive effort needed to learn and to utilize the new IT (Gefen et al., 2003). Internet shopping enables customers to save their time and effort when purchasing desired products (Park \& Yoon, 2001).

It is worth pointing out, in this context, that if a speedy connection to ( $\mathrm{Li}$ et al., 2005), a quick search of (Shin et al., 2001), a convenient purchasing process at (Shin et al., 2001; Chi \& Yeom, 1999), and a concise and quick payment at (Li et al., 2005) the Web site can be provided and available, customer's PEOU in the Internet shopping malls occurs. Especially, fast access to Internet or a Web site may have a key influence on a consumer's purchasing intention. We have extended discussion on this issue in the discussion and conclusion part of this paper.

\section{RESEARCH MODEL AND HYPOTHESES}

\subsection{Research Model}

Based on the relevant concepts discussed above, a research model is suggested to examine the direct and mediating effects of Internet shoppers' trust on purchasing intention in China C2C market. It is shown in Figure 1. 


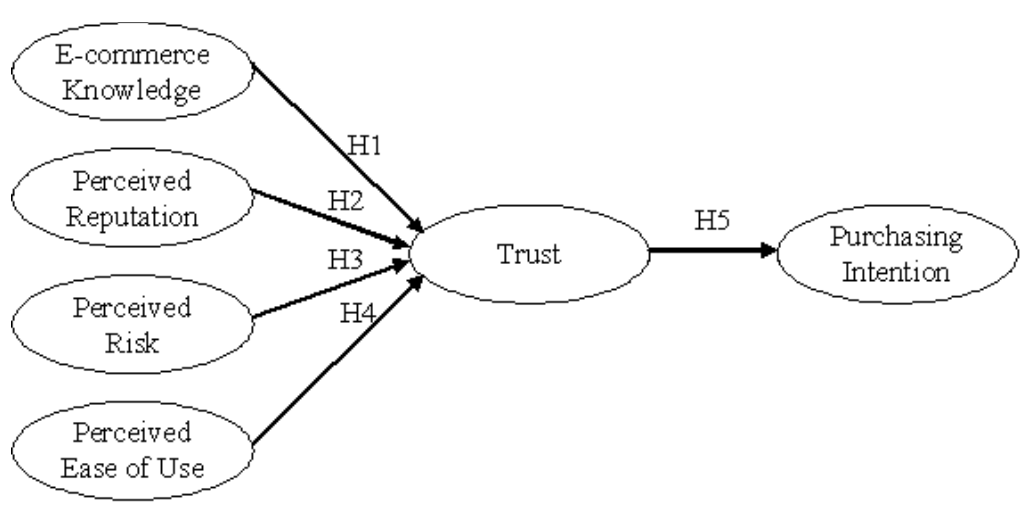

Figure 1. Research Model

In this model, the theoretical relationships of all the variables have been incorporated in the Internet shopping context. A consumer's intention to purchase products from Internet shopping malls is contingent on a consumer's trust. Consumers are less likely to patronize stores that fail to create a sense of trustworthiness and an easily usable context. In the meantime, trust would also be influenced by e-commerce knowledge, perceived reputation, perceived risk, and perceived ease of use, all of which are set as independent variables in the model. Hence trust serves as a mediating variable while purchasing intention is a dependent variable. Based on this model, relationships among the variables are hypothesized below.

\subsubsection{E-commerce Knowledge and trust}

As has been pointed out, e-commerce knowledge is the knowledge about product searching through an Internet shopping mall, purchasing methods, payment processes, individual information protection policies, etc. To express the concept of ecommerce knowledge in another way, e-commerce knowledge can be equivalent to a familiarity which corresponds to how well a consumer comprehends a Web site's procedures including when and how to enter credit and other required information in the e-commerce Web site (Gefen, 2003). More familiarity implies an increasing amount of accumulated knowledge derived from experience of previous successful interactions through the Web site (Gefen, 2003). Then the accumulated trust-relevant knowledge lead to higher levels of trust in turn.

In parallel, as we mentioned before, e-commerce knowledge is regarded as a kind of skill as well (Novak et al., 2000). This skill is similar to computer self-efficacy, which can be defined as an individual judgment of his/her capability in using an Internet shopping mall (Koufaris, 2002). Only when consumers perceive that their own skills are able to make them capable of performing Internet shopping can consumer trust occur. Otherwise, consumers may become bored or anxious (Ellis et al., 1994).

Therefore, with respect to e-commerce knowledge, we can reasonably hypothesize:

H: E-commerce knowledge will positively affect consumer trust in an Internet 
shopping mall.

\subsubsection{Perceived Reputation and Trust}

As reputation is a valuable asset, sellers usually try to avoid getting a bad reputation. A vendor can signal its trustworthiness by building a good reputation. Reputation is a main characteristic of a vendor's trustworthiness (Doney \& Cannon, 1997). Reputation requires a long-term investment of resources, effort, and attention to the customer relationship. Since reputation represents a third-party or public opinion of the vendor, it must be transferred from the third party or the public to customers, influencing them to build trust in the Internet shopping mall owned by the vendor.

Not only a potential customer but also a repeat customer can build trust through the perception of the good reputation that an Internet shopping mall has. When a potential customer has little or no direct experience with the vendor, the third-party opinion about the trustworthiness of the Internet shopping malls can be a major source of information for trust building. Moreover, repeat customers estimate the trustworthiness of the Internet shopping mall by its reputation (Kim et al., 2004). The better the seller's reputation, the more the mall has presumably committed resources to build that reputation and the higher the penalty when violating a consumer's trust. Hence, the more trustworthy the seller is perceived to be (Jarvenpaa \& Tractinsky, 1999). Doney \& Cannon (1997) also find that a supplier firm's reputation invokes the trust building-process and it serves as a significant factor on the calculative step and transference step of the trust-building process. Retailers are probably a big part of ecustomers in B2B market. Their favorable perception of an e-vendor's reputation leads to its increased credibility which is one of the two dimensions of trust (Ganesan, 1994).

At the same time, perceived reputation is regarded as a kind of indirect information. Indirect information cannot provide consumers with as much belief as direct information that is collected during an actual Internet shopping experience. However, for those consumers who are short of purchasing experience in using an Internet shopping mall, indirect information works as a sort of piece of key information to establish their trust (Lee \& Lee, 2003).

In general, e-vendors with a good reputation recognize that there should be a great loss of reputation if they act unreliably. The recognition becomes much stronger especially in the case that the consumer network remains small-scaled and the opportunities for communication or interaction between consumers are increasing (Jong $\&$ Lee, 2000). Thus, we set up the following hypothesis:

$\mathrm{H}$ : The perceived reputation of an Internet shopping mall is positively associated with consumer trust.

\subsubsection{Perceived Risk and Trust}

The Internet is an open, global, and constantly changing marketing channel. The Internet shopping malls in the virtual channel makes it hard to inspect physical goods (Jarvenpaa \& Tractinsky, 1999). Compared to the traditional offline marketing channel, an e-customer can get less assurance of transaction safety and product quality. 
Moreover, when problems arise, sellers will probably attribute them to technical problems or systems problems. All these increase the uncertainty and may result in adverse consequences for those engaged in transaction activities. When perceived risk is present and it is increasing, consumers' trust will suffer.

Ratnasinghams (1998) argues that if e-commerce is to become the dominant business platform of the next millennium, systems should be integrated and the transaction process should be standardized to ensure that any business transaction is operated in a secure way. By addressing every aspect of a consumer's concern, the consumer can place complete reliance on the confidentiality, security, integrity, and availability of information processed and stored.

$\mathrm{H}$ : Perceived risk will reduce consumer trust.

\subsubsection{Perceived Ease of Use and Trust (PEOU)}

PEOU is one of the major constructs of the technology acceptance model (TAM). Improving PEOU is an issue that has received attention of researchers for over a decade. Many researchers cited in this paper have agreed that TAM can be used to study the purchasing intention by treating an Internet shopping mall as a technical system and the consumers as technology users. When consumers believe that a Web site is easy to use and thus have perceived ease of use, they are more likely to go shopping to that Web site (Koufaris, 2002).

A considerable amount of restrictions that used to exist in traditional transactions have disappeared in virtual space. Thus, Internet shopping becomes a new powerful kind of transaction (Kim \& Park, 2002). The easier executing this kind of transaction is made for consumers, the more transactions will be likely to occur (Gefen et al., 2003). In the meantime, Venkatesh \& Viswanath (2000) suggest that individuals attempt to minimize effort in their behaviors, which supports a relationship between consumer's PEOU and their usage behavior. PEOU in Internet shopping malls is defined as a catalyst for the revitalization of e-transaction (Han \& Noh, 1998). Ko \& Mok (1999) also suggest that the PEOU is a key factor of consumer satisfaction.

$\mathrm{H}$ : Perceived ease of use will positively affect consumer trust.

\subsubsection{Trust and Purchasing Intention}

In Jarvenpaa \& Tractinsky (1999)'s research, trust is described as having an indirect influence on purchasing intention. As the researchers suggest, a consumer's willingness to buy from an Internet seller is contingent on the consumer's attitude towards the store. This attitude, in turn, is affected by the seller's ability to evoke consumer's trust. However, most other prior researchers refer to trust as a key factor that directly has a great influence on purchasing intent. Trust helps reduce the social complexity that a consumer faces in e-commerce by allowing the consumer to subjectively rule out undesirable yet possible behaviors of the e-vendor including inappropriate use of purchase information. In this way trust encourages business activities of online customers (Gefen et al., 2003). According to reasoned action theory, 
Internet shopping activity can be referred to as a kind of intentional activity phenomenon affected strongly by consumer trust as well (Jong \& Lee, 2000). Some other studies also suggest that there exists a direct and significant relationship between trust and purchasing intention (Jang et al., 2005; Yu \& Choe, 2003; Yoon, 2000).

Based on most of the prior studies that have demonstrated the direct influence of trust on purchasing intention, the following hypothesis is suggested in this study:

$\mathrm{H}$ : Higher consumer trust on an Internet shopping mall will generate more purchasing intention in that Internet shopping mall.

\subsection{Operationalization of the Research Variables}

Operational definitions and measurements of the research variables are provided in Table 1. We developed outcome variables based on relevant literature. The variables were measured by a seven-point Likert scale ( $1=$ strongly disagree, $7=$ strongly agree).

[Table 1] Operational Definitions and Measures of the Variables

\begin{tabular}{|c|c|c|c|}
\hline Variable & Operational Definition & Measurement & Reference \\
\hline Trust & $\begin{array}{l}\text { A set of specific beliefs dealing } \\
\text { primarily with the integrity, } \\
\text { benevolence, and ability of another } \\
\text { party' }\end{array}$ & $\begin{array}{l}\text { 1. Effort to meet customer } \\
\text { satisfaction } \\
\text { 2. Customer care } \\
\text { 3. Trust worthiness } \\
\text { 4. Effort to provide high quality } \\
\text { service }\end{array}$ & $\begin{array}{l}\text { Gefen et al., } \\
2003\end{array}$ \\
\hline $\begin{array}{l}\text { E-commerce } \\
\text { Knowledge }\end{array}$ & $\begin{array}{l}\text { A kind of knowledge about product } \\
\text { searching through the Internet } \\
\text { shopping mall, purchasing method, } \\
\text { payment process and individual } \\
\text { information protection policy, etc. }\end{array}$ & $\begin{array}{l}\text { 1. Familiarity with the online } \\
\text { shopping process } \\
\text { 2. Familiarity with the online } \\
\text { shopping method } \\
\text { 3. Familiarity with the online } \\
\text { payment process } \\
\begin{array}{l}\text { 4. Familiarity with the online } \\
\text { returning process }\end{array}\end{array}$ & $\begin{array}{l}\text { Baek et al., } \\
2006\end{array}$ \\
\hline $\begin{array}{l}\text { Perceived } \\
\text { Reputation }\end{array}$ & $\begin{array}{l}\text { A customer's perception of the } \\
\text { Internet shopping mall's reputation }\end{array}$ & $\begin{array}{l}\text { 1. Good reputation } \\
\text { 2. Effort to make itself regarded } \\
\text { favorably } \\
\text { 3. Good image }\end{array}$ & $\begin{array}{l}\text { Jong \& Lee, } \\
2000\end{array}$ \\
\hline Perceived Risk & $\begin{array}{l}\text { A consumer's perceptions of the } \\
\text { uncertainty and adverse } \\
\text { consequences of engaging in an } \\
\text { activity }\end{array}$ & $\begin{array}{l}\text { 1. More risk compared with other } \\
\text { ways of shopping } \\
\text { 2. Low security } \\
\text { 3. Difference between the } \\
\text { purchased product and the product } \\
\text { actually delivered } \\
\text { 4. Low product quality } \\
\text { 5. Harm to human body } \\
\text { 6. Uncertainty associated with } \\
\text { Internet shopping }\end{array}$ & $\begin{array}{l}\text { Dowling \& } \\
\text { Staelin, } 1994\end{array}$ \\
\hline
\end{tabular}




\begin{tabular}{|l|l|l|c|}
\hline & & $\begin{array}{l}\text { 1. Time and effort saving } \\
\text { 2. Convenience of doing Internet } \\
\text { shopping }\end{array}$ & Gefen et al., \\
PEOU & $\begin{array}{l}\text { An indicator of the cognitive effort } \\
\text { needed to learn and to utilize the } \\
\text { new IT }\end{array}$ & $\begin{array}{l}\text { remembered URL } \\
\text { 4. Effort to provide concise and } \\
\text { quick payment methods }\end{array}$ & 2003 \\
\hline
\end{tabular}

\section{RESEARCH METHOD}

\subsection{Data Collection}

To test our research model, a survey was conducted. In this survey, all the participants answering the questionnaire are Chinese who live in China, regardless of whether they had had an Internet shopping experience before or not. Respondents were not informed about the objective of this survey. This survey lasted for 4 months, from Dec. 2006 to Mar. 2007. Among the 187 respondents, $72.1 \%$ said that they frequently had Internet shopping experience with Taobao.com; 36.4\% with Ebay.com.cn; 28.9\% with Paipai.com; 49.2\% with Dangdang.com; 11.2\% with Joyo.com; 36.4\% with others; and $3.2 \%$ had no Internet shopping experience at all. These are the result of multiple selection. The demographics profiles of the 187 participants, taking part in the survey, are summarized in Table 2.

[Table 2] Sample Characteristics $(n=187)$

\begin{tabular}{|c|c|c|c|c|c|c|c|}
\hline Measure & Items & Frequency & Percent & Measure & Items & Frequency & Percent \\
\hline \multirow[b]{2}{*}{ Gender } & female & 101 & $54 \%$ & \multirow{4}{*}{$\begin{array}{c}\text { Years of } \\
\text { Internet } \\
\text { experience }\end{array}$} & $<1$ year & 0 & N/A \\
\hline & male & 86 & $46 \%$ & & $\begin{array}{c}1-3 \\
\text { years(3 } \\
\text { included) }\end{array}$ & 36 & $19.30 \%$ \\
\hline \multirow{5}{*}{ Age } & $<20$ & 10 & $5.30 \%$ & & $3-5$ years & 50 & $26.70 \%$ \\
\hline & $\begin{array}{c}20-30(30 \text { not } \\
\text { included })\end{array}$ & 108 & $57.80 \%$ & & $>5$ years & 101 & $54 \%$ \\
\hline & $\begin{array}{l}30-40(40 \text { not } \\
\text { included) }\end{array}$ & 40 & $21.40 \%$ & \multirow{4}{*}{$\begin{array}{c}\text { Internet } \\
\text { shopping } \\
\text { experience }\end{array}$} & never & 0 & N/A \\
\hline & $40-50$ & 18 & $9.60 \%$ & & $<5$ times & 61 & $32.60 \%$ \\
\hline & $>50$ & 11 & $5.90 \%$ & & $\begin{array}{l}5-20 \\
\text { times }\end{array}$ & 100 & $53.50 \%$ \\
\hline \multirow{6}{*}{ Profession } & employee & 75 & $40.10 \%$ & & $>20$ times & 26 & $13.90 \%$ \\
\hline & self-employed & 3 & $1.60 \%$ & \multirow{3}{*}{$\begin{array}{c}\text { Frequency } \\
\text { of access to } \\
\text { an Internet } \\
\begin{array}{c}\text { Shopping } \\
\text { site }\end{array}\end{array}$} & $\begin{array}{l}\leq \text { once a } \\
\text { month }\end{array}$ & 52 & $27.80 \%$ \\
\hline & student & 78 & $41.70 \%$ & & $\begin{array}{c}1-10 \\
\text { times per } \\
\text { month }\end{array}$ & 89 & $47.60 \%$ \\
\hline & professional & 12 & $6.40 \%$ & & $\begin{array}{l}>10 \text { times } \\
\text { per month }\end{array}$ & 46 & $24.60 \%$ \\
\hline & housewife & 7 & $3.70 \%$ & \multirow{5}{*}{$\begin{array}{c}\text { Internet } \\
\text { access } \\
\text { place }\end{array}$} & home & 83 & $44.40 \%$ \\
\hline & other & 12 & $6.40 \%$ & & office & 57 & $30.50 \%$ \\
\hline \multirow{3}{*}{$\begin{array}{l}\text { Internet } \\
\text { access } \\
\text { method }\end{array}$} & dial-up & 30 & $16 \%$ & & school & 39 & $20.90 \%$ \\
\hline & $\begin{array}{c}\text { broadband or } \\
\text { leased line }\end{array}$ & 148 & $79.10 \%$ & & PC cafe & 6 & $3.20 \%$ \\
\hline & others & 9 & $4.90 \%$ & & others & 2 & $1 \%$ \\
\hline
\end{tabular}




\subsection{ANALYSIS AND TESTING}

\subsubsection{Reliability and Validity}

The internal consistency reliability of the variables was assessed by computing Cronbach's alphas. The Cronbach's alpha values of all the variables, ranging from 0.768 to 0.876 , were well over 0.700 , which was considered satisfactory for measures (Nunally, 1978).

Each variable was measured with multiple items. A factor analysis was conducted to check their unintentionality. To test for the construct validity of a variable, a principal-component factor analysis was conducted with a VARIMAX rotation. The results of factor analysis are shown in Table 3. Most of the factor loadings for the items appear above 0.6. The items were collected corresponding to each singular factor demonstrating a high convergent validity. As the factor loadings for a variable (factor) are bigger than the factor loadings for the other variables, it supports the instrument's discriminant validity (Chin, 1998).

[Table 3] Factor Analysis Results for Variables

\begin{tabular}{|c|c|c|c|c|c|c|}
\hline & \multicolumn{5}{|c|}{ Component } & \multirow{2}{*}{$\begin{array}{c}\text { Cronbach's } \\
\text { Alpha( }(\boldsymbol{\alpha}) \\
\end{array}$} \\
\hline & 1 & 2 & 3 & 4 & 5 & \\
\hline RISK6 & .779 & -.148 & -.175 & .016 & -.006 & \multirow{6}{*}{0.829} \\
\hline RISK7 & .747 & .020 & .033 & -.075 & -.279 & \\
\hline RISK8 & .745 & .106 & -.163 & -.068 & -.078 & \\
\hline RISK12 & .710 & -.286 & -.113 & .023 & .017 & \\
\hline RISK13 & .691 & -.143 & -.149 & -.327 & .176 & \\
\hline RISK4 & .536 & -.175 & -.325 & -.043 & -.299 & \\
\hline ECK1 & -.052 & .816 & .286 & .261 & .084 & \multirow{4}{*}{0.873} \\
\hline ECK2 & -.082 & .799 & .273 & .250 & .154 & \\
\hline ECK3 & -.128 & .794 & .282 & .210 & .027 & \\
\hline ECK4 & -.175 & .719 & .016 & -.039 & .250 & \\
\hline TRU5 & -.180 & .145 & .797 & .140 & .224 & \multirow{4}{*}{0.854} \\
\hline TRU7 & -.150 & .213 & .774 & .213 & -.030 & \\
\hline TRU6 & -.175 & .299 & .731 & .320 & .142 & \\
\hline TRU4 & -.175 & .158 & .711 & -.039 & .196 & \\
\hline PEOU2 & -.069 & .021 & .260 & .786 & .160 & \multirow{4}{*}{0.768} \\
\hline PEOU1 & -.201 & .118 & .330 & .714 & .233 & \\
\hline PEOU5 & -.045 & .136 & -.065 & .645 & .236 & \\
\hline PEOU3 & -.005 & .322 & .084 & .627 & .092 & \\
\hline REP1 & -.005 & 239 & .072 & .155 & .836 & \multirow{3}{*}{0.876} \\
\hline REP2 & -.132 & .116 & .176 & .276 & .820 & \\
\hline REP3 & -.124 & .084 & 268 & .283 & .777 & \\
\hline Eigenvalue & 7.382 & 2.434 & 1.855 & 1.403 & 1.293 & \multirow{3}{*}{-} \\
\hline $\begin{array}{c}\text { Percentage of } \\
\text { Variance Explained }\end{array}$ & 35.153 & 11.59 & 8.834 & 6.679 & 6.158 & \\
\hline $\begin{array}{l}\text { Cumulative } \\
\text { Percentage }\end{array}$ & 35.153 & 46.743 & 55.577 & 62.256 & 68.414 & \\
\hline
\end{tabular}


$\cdot$ RISK : Perceived Risk

- ECK : Electronic Commerce Knowledge

$\cdot$ TRU : Trust

- PEOU: Perceived Ease of Use

$\cdot$ REP : Perceived Reputation

\subsubsection{Hypothesis Testing}

The simple correlation among all of the research variables is shown in Table 4. A Pearson correlation was calculated for the variables measured by interval or ratio scales. Before conducting the multiple regression analysis, we checked potential multicollinearity among the antecedents since some variables were significantly correlated to others. Though several variables showed significant correlations, their tolerance values, given by the SPSS 12.0 statistical application, running on a Windows $\mathrm{PC}$, ranged from 0.387 to 0.956 , indicating that multicollinearity was not a likely threat to the parameter estimates (Hair et al., 1995).

[Table 4] Correlation Analysis between the Research Variables ( $\mathrm{n}=187)$

\begin{tabular}{|l|c|c|c|c|c|}
\hline & 1 & 2 & 3 & 4 & 5 \\
\hline 1. E-commerce Knowledge & - & & & & \\
2. Trust & $.523 * * *$ & - & & & \\
3. Purchasing Intention & $.432 * * *$ & $.608 * * *$ & - & & \\
4. Perceived Ease Of Use & $.448 * * *$ & $.473 * * *$ & $.520 * * *$ & - & \\
5. Perceived Risk & $-.329 * * *$ & $-.440 * * *$ & $-.399 * * *$ & $-.289 * * *$ & - \\
6. Perceived Reputation & $.393 * * *$ & $.414 * * *$ & $.362 * * *$ & $.506 * * *$ & $-.276 * * *$ \\
\hline$* * * \mathrm{p}<0.01$
\end{tabular}

Table 5 shows the results of the multiple regression analysis testing the five hypotheses. The results indicate that the two regression models were significant at the $\mathrm{p}<0.01$ level (F-value $=32.222$ and 108.708). Also, the predictors of each model explained $40 \%$ and $37 \%$ of the total variance, respectively. In Hypotheses H1- H4, ecommerce knowledge, perceived risk, and perceived ease of use were significantly related to trust $(\beta=0.301, \mathrm{p}<0.01 ; \beta=-0.093, \mathrm{p}<0.01 ; \beta=0.203, \mathrm{p}<0.01)$.

However, perceived reputation was not significantly related to trust. Hence, Hypothesis H2 was not one of the supported hypotheses; while the other hypotheses were supported. In Hypothesis H5, trust was significantly related to purchasing intention $(\beta=0.608, \mathrm{p}<0.01)$. Consequently, Hypothesis H1, H3, H4, and H5 were 
supported.

[Table 5] Results of the Hypotheses Tests (From H1 to H5)

\begin{tabular}{|c|c|c|c|c|c|c|}
\hline Model & $\mathrm{R}^{2}$ & $\begin{array}{l}\text { adj. } \\
\mathrm{R}^{2}\end{array}$ & $\mathrm{~F}$ & $\begin{array}{c}\text { Standardized } \\
\text { coefficient } \\
(\beta)\end{array}$ & Tolerance & Results \\
\hline $\begin{array}{l}\text { (1) Trust (TRU) } \\
\text { TRU = } \\
\text { ECK+REP+RISK+PEOU+errors } \\
\text { ECK (E-commerce Knowledge) } \\
\text { REP (Perceived Reputation) } \\
\text { RISK (Perceived Risk) } \\
\text { PEOU (Perceived Ease of Use) }\end{array}$ & 0.415 & 0.402 & $32.222^{* * *}$ & $\begin{array}{l}0.301^{* * *} \\
0.125^{\text {*** }} \\
-0.093^{* * *} \\
0.203^{* * *}\end{array}$ & $\begin{array}{l}0.730 \\
0.701 \\
0.855 \\
0.663\end{array}$ & $\begin{array}{l}\text { H-1 was } \\
\text { supported } \\
\text { H-2 was } \\
\text { not } \\
\text { supported } \\
\text { H-3 was } \\
\text { supported } \\
\text { H-4 was } \\
\text { supported }\end{array}$ \\
\hline $\begin{array}{l}\text { (2) PI (Purchasing Intention) } \\
\text { PI = TRU+errors } \\
\text { TRU (Trust) }\end{array}$ & 0.370 & 0.367 & $108.708^{* * *}$ & $0.608^{* * *}$ & 1.000 & $\begin{array}{l}\text { H-5 was } \\
\text { supported }\end{array}$ \\
\hline
\end{tabular}

$* * \mathrm{p}<0.05, * * * \mathrm{p}<0.01$

\section{DISCUSSION AND IMPLICATIONS}

\subsection{Discussion}

This study has found that trust has a strong significant relationship with purchasing intention. In other words, greater consumer trust motivates customers generate more intention to purchase in the Internet shopping mall. We also confirmed that trust should be built first if a Chinese e-vendor wants to improve its Web site's competence.

While a few previous studies have proposed e-commerce knowledge as an important trust-building factor for Internet shopping malls, this study found it as a key antecedent of trust. This finding makes sense because of the fact that in China, unlike in Korea or in other advanced economies, only a fraction of the Internet users have a clear idea about the e-shopping method and processes involved to make them have strong trust on an Internet shopping mall. Other Chinese Internet users probably doubt an eshopping Web site due to lack of e-commerce knowledge. In other words, the amount of e-commerce knowledge directly influences Chinese consumers' judgments on an Internet shopping mall's trustworthiness. On the other hand, in some developed emarkets such as Korea, U.S.A, and Japan, almost every Internet user has some amount of e-commerce knowledge, so few studies treat e-commerce knowledge as a research variable in trust context.

In addition, we found that perceived reputation does not have a statistically significant relationship with trust while e-commerce knowledge, perceived risk, and PEOU do. It is probably because several largest Internet shopping malls have occupied 
most of China's C2C and B2C markets (Tabao.com, Ebay.com.cn, Paipai.com, Dangdang.com, and Joyo.com) that a majority of e-consumers purchase products only through these big Web sites. As a consequence, it makes it difficult for consumers to identify whether there are any distinct effects on trust caused by reputation or not. Furthermore, we came to understand by the demographic statistics above that most respondents were customers with prior e-shopping experience (repeat customers). According to Kim et al. (2004), reputation usually has a weaker effect on repeat customers' trust than on potential new customers.

Regarding perceived risk, like many other prior research efforts, we also found it to be significant to trust. Uncertainty of the purchasing process, perception of little guarantee on quality and after sales services, wariness about the privacy issue, etc. still remain as obstacles in the relationships between consumers and Internet shopping malls in China.

Finally, PEOU is found to play another key role on the generation of trust. When consumers view an Internet shopping mall as a Web site providing quick search, a convenient purchasing process (Shin et al., 2001), speedy access and concise payment (Li et al., 2005), they will probably trust this Internet shopping mall and intend to purchase in that Web site.

\subsection{Implications}

Trust is found to be a key factor in this e-commerce context according to many previous studies (Jarvenpaa and Tractinsky, 1999; Gefen, 2003; Jong et al., 2006; Doney \& Cannon, 1997; Park, 2005; Jang et al., 2005). This study also confirms that trust can strongly affect e-shoppers' intention to purchase products at an Internet shopping mall. Trust can also mediate the influence of consumers' characteristics and perceptions such as e-commerce knowledge, perceived risk, and perceived ease of use on their purchasing intention as well. Thus this trust factor is worthwhile to be included in further studies on e-commerce.

In addition, e-commerce knowledge was found to be a key trust building factor while perceived reputation was not. This result is totally different from a majority of previous studies. It is probably because of this study's special research context, that is, e-commerce in China. We believe it to be highly desirable for researchers to conduct more e-commerce research based on a specific market or other contexts in their future work.

Since trust has proven to have a significant effect on purchasing intention, China's e-vendors as well as the Chinese government should work out some measures to build strong consumer trust in order to accelerate the development of China's eshopping market. Below are some suggestions based on this study.

1. Education and training on the Internet and on e-shopping as well as related support should be provided by the Chinese government and Internet shopping mall providers. This will be a significant contributor toward building consumers' trust.

2. According to consumers' different perceptions of risk, different measures should be taken to relieve their wariness. 
3. Systems used in implementing Internet shopping malls should be augmented continuously in order to meet and exceed consumer's requirements for easy-to-use Web sites.

4. Due to trust's critical role in the e-commerce context, it is necessary for the Chinese government and Internet shopping mall providers to include in their goals consumer trust building when taking actions targeted at increasing customer purchasing on their sites. Actions for solving such problems as consumers' lack of e-commerce knowledge, wariness about the various risks, and perceived inconvenience of use during Internet shopping should be targeted at contributing to building and increasing consumer's trust. In fact, at ebay.com.cn, there are many trust-building education oriented contents provided for consumers for free in such areas as payment protection policy, assurance on refund, and other contents.

\subsection{Study Limitations and Future Research Directions}

We acknowledge several limitations in this study. First, the survey should have covered a more general population instead of mainly including college students, even though the majority of e-consumers are aged 18-30 (CNNIC, 2007). Second, unlike many previous studies that have dealt with e-consumers' purchasing intention or econsumer trust, the concept "consumer" has not been separated into potential and repeat consumers. If this separation is made clearly from the beginning, it could be possible that different kinds of consumers' purchasing intention might relate to different variables (Kim et al., 2004). However, all the respondents answered that they had prior Internet shopping experience, that is, the subjects of this survey, fortunately enough, turned out to be repeat consumers. Third, similar to splitting consumers into two groups based on experience, China's e-shopping market can also be broken into B2C and C2C markets for study. Thus more thoughtful market segmentation will result in better explanation in the study of trust and its effects on purchasing intention.

\section{REFERENCES}

Baek, C.H., Seo C.S., Hong, J.W. and Suh, W.J. (2006). "Empirical Research about the Effects on Customer Trust and Purchase Intention in China Internet shopping mall," Spring Semi Annual Conferences of KMIS, pp.548-555.

Chi, H.W. and Yeom, C.S. (1999). "Empirical Research about Effects on Consumer Satisfaction of Internet shopping mall," Combination Conference of KAIS, pp. 621-626.

Chin, W.W. (1998). "Issues and Opinion on Structural Equation Modeling," MIS Quarterly, Vol.22, No. 1, pp. 7-16.

China Internet Network Information Center(CNNIC) (2007), "The 19th Survey Report of Internet Development in China," 2007, http://www.cnnic.net.cn/uploadfiles/pdf/2007/2/14/200607.pdf.

Doney, P.M., and Cannon, J.P. (1997). “An Examination of the Nature of Trust in 
Buyer-Seller Relationships,"Journal of Marketing, Vol. 61, pp. 35-51.

Dowling, G.R., and Staelin, R. (1994). "A Model of Perceived Risk and Intended RiskHandling Activity," Journal of Consumer Research, Vol. 21, pp. 19-134.

Ellis, G.D., Judith, E.V. and Catherine M. (1994). "Measurement and Analysis Issues with Explanation of Variance in Daily Experience Using the Flow Model," Leisure Res, Vol. 26, No. 4, pp. 337-356.

Ganesan, S. (1994). "Determinants of Long-Term Orientation in Buyer-Seller Relationships," Journal of Marketing, Vol. 58, No. 2, pp. 1-19.

Gefen, D., and Silver, M. (1999). "Lessons Learned from the Successful Adoption of an ERP System," Proceedings of the 5th International Conference of the Decision Science Institute, pp.1054-1057.

Gefen, D., Karahanna, E. and Straub D.W. (2003). "Trust and Tam in Online Shopping: an Integrated Model.” MIS Quarterly, Vol. 27, No. 1, pp. 51-99.

Hair. J.F., Aderson, R.E., Tatham, R.L., Black. W.C. (1998)." Multivariate Data Analysis. 5th edition, " Prentice - Hall.

Hosmer, L.T. (1995). "Trust: the Connecting Link between Organizational Theory and Philosophical Ethics," Academy of Management Review, Vol. 20, No. 2, pp. 379-403.

Jang, H.Y., Jeong, K.H., Jeong, D.Y. (2005). "The Consequences of Customer Trust and the Determinants of Purchasing Intention in Internet shopping mall," Journal of MIS Research, Vol. 15, No.2, pp. 23-49.

Jarvenpaa, S.L. and Tractinsky, N. (1999). "Consumer Trust in an Internet Store: A Cross-Cultural Validation,” JCMC, Vol. 5, No. 2, pp. 1-35.

Jeong, C.H., Jeong, Y.S. and Lee, K. (2006). "Research about the Effects of Internet shopping mall User Trust on Royalty: Comparison Analysis between Korea and China Trust Determinate Factors," Spring Semi Annual Conferences of KMIS, pp. 659-666.

Jong, K.E. and Lee, D.M. (2000). "Research about Consumer Trust on Internet shopping mall," Fall Semi Annual Conferences of KMIS, pp. 561-573.

Kim, H.W., Xu, Y., Koh, J. (2004). "A Comparison of Trust Building Factors between Potential Customers and Repeat Customers," Journal of the Association for Information Systems, Vol. 5, No. 10, pp. 392-420.

Kim, S.W. and Park, B.J. (2002). "An Empirical Study on Consumer Purchase Behavior by the Benefit in Internet shopping mall," Journal of Consumer Studies, Vol. 13, No. 4, pp. 201-219.

Kim, S.Y. and Park, S.Y. (1999). "A Study of Decision Factors for Purchase Intention at the Electronic Commerce," Journal of Consumer Studies, Vol. 10, No. 3, pp. 45-66.

Ko, E.J. and Mok, B.K. (1999). "Analysis of Internet Shopping Process to Develop the Web Design Strategy for Apparel Consumers," Journal of Korean Academy of marketing Science, Vol. 4, pp. 111-131.

Koufaris, M. (2002). "Applying the Technology Acceptance Model and Flow Theory to Online Consumer Behavior," Information Systems Research, Vol. 13, No. 2, pp. 205- 
223.

Lee, T.M. and Lee, E.Y. (2005). "A Study on the Determinants of Purchase Intention in Mobile Commerce: Focused on the Mediating Role of Perceived Risks and Perceived Benefits," Journal of MIS Research, Vol. 15, No. 2, pp. 1-21.

Lee, Y.K. and Lee, K.Y. (2003). "The Effect of Perceived Trustworthiness on Consumer Trust in Internet Store," Korean Industrial Economic Association, Vol. 16, No. 3, pp. 127-140.

Li, M.Z., Han, K.S. and Kim, G.Y. (2005). "An Empirical Study on the Utilizing Conditions of Online Shopping Mall of Chinese Consumers - focused on Beijing and Shanghai," Internet business Research, Vol. 6, No. 2, pp.55-78

Mayer, R.C., Davis, J.H. and Schoorman, F.D. (1995). "An Integrative Model of Organizational Trust,” Academy of Management Review, Vol. 20, No. 3, pp. 709-734.

McKnight, D.H., Cummings, L.L. and Chervany, N.L. (1998). "Initial Trust Formation in New Organizational Relationships (Special Topic Forum on Trust in and Between Organizations)", Academy of Management Review, Vol. 23, No. 3, pp. 472-490.

Novak, T.P., Hoffman, D.L. and Yung, Y.F. (2000). "Measuring the Customer Experience in online Environments: A Structural Modeling Approach," Marketing Science, Vol. 19, No. 1, pp. 22-42.

Nunnally, J. (1978). Psychometric Theory, 2nd ed., McGraw-Hill, New York.

Park, H.R. (2005). "Effects of Consumer's Characteristics on Trust and Purchase Intention of On-Line Shopping Mall - Focusing on Chinese Users of Internet shopping mall," Journal of The Korean Society for Clothing Industry, Vol. 7, No. 5, pp. 501-508.

Park, J.C. and Yoon, M.H. (2002). " Factors Affecting on Internet shopping mall Members`Relationship Quality," Journal of MIS Research, Vol. 12, No. 3, pp. 21-43.

Ratnasingham, P. (1998). "The Importance of Trust in Electronic Commerce." Internet Research, Vol.8, No. 4, pp. 313-321.

Shin, K.Y., Choo, G.W. and Park, T.J. (2001). "Determinants of Using Internet shopping malls," Journal of MIS Research, Vol. 10, No. 1, pp. 279-301.

Shin, M.K., Joung, S.H. and Yuh, Y.K. (2004). "Consumer's Perceived Risk and Information Search in Internet Shopping," The Journal of Korean Home Economics Association, Vol. 42, No. 9, pp. 195-212.

Viswanath, V. (2000). "Determinants of Perceived Ease of Use: Integrating Control, Intrinsic Motivation, and Emotion into the Technology Acceptance model." Information Systems Research, Vol. 11, No. 4, pp. 342-365.

Yang, Y. and Baeg, W.Su. (2003). "Perceived Risks and Consumer Characteristics on Internet Shopping," Korean Journal of Consumer and Advertising Psychology, Vol.4, No. 2, pp. 73-103.

Yoon, S.J. (2000). "A Study on the Antecedents of Trust toward Shopping Mall Web Sites and Its Effects on Purchase Intention," Journal of Business Administration, Vol. 29, No.3, pp. 353-376.

Yu, I. and Choe, H.L. (2003). "Factors Influencing the Consumer Trust and Mediating 
Roles of Trust on Purchasing Intention in B2C Electronic Commerce," Journal of MIS Research, Vol. 13, No.4, pp. 49-72. 